written and a different exposition to the existing one should be given by teachers of geography and geology.

Excursions were conducted to Eridge Park and Costume Museum, and to Lewes, where the historic buildings were described by Mrs. E. Bradley, while material of interest to the botanists and zoologists on the Levels was shown by Dr. Langmead.

The sixty-second annual congress of the Union will be held next year in Hastings during April.

\section{NATIONAL RESEARCH DEVELOPMENT CORPORATION}

\section{ANNUAL REPORT FOR 1954-55}

THE report and statement of accounts of the National Research Development Corporation for the year ended June $30,1955^{*}$, records only 135 cases of assignment of United Kingdom patent rights to the Corporation by government departments and research councils, compared with 315 during 1953-54. of the 597 inventions communicated to the Corporation during 1954-55 (compared with 664 during 1953-54), 203 were from government departments and research councils, 22 from official organizations of the British Commonwealth, 8 from industrial research associations, 54 from universities and 310 from private firms and individuals, 283 of which were British. Patent rights assigned to the Corporation during the year totalled 187, including 42 from universities and 9 from industrial research associations; holdings of British and foreign patents and patent applications at June 30,1955 , included 492 United Kingdom applications and 522 granted patents, and 982 overseas patent applications and 639 granted patents. The accounts show a rising trend in the return from the Corporation's activities when compared with its outgoings, the annual income of $£ 94,749$ during $1954-55$ representing $61 \cdot 3$ per cent of the expenditure.

Of the projects initiated in previous years, the report notes that four of the six big electronic digital computers had been delivered, installed and accepted by June 30, 1955. The ' 401 ' computer, leased to the Agricultural Research Council, continues to operate satisfactorily at Rothamsted Experimental Station and has also been used in developing a numerical technique for predicting the predisposition of an aircraft to aerodynamic 'flutter', in which it has been demonstrated that the flutter speeds and frequencies may be conveniently and quickly computed by digital equipment. In addition, it has been used for computing the optimum trajectories of particles under acceleration in a cyclotron, with contributions to the understanding of cyclotron design. The response to grants for training computer engineers at the Universities of Manchester and Cambridge has been small. Uncertainties of marketing conditions and the absence of firm orders appear to be the chief barriers to obtaining licences for the Ricardo light steam engine, and prototype installations were being placed at the disposal of some Commonwealth governments for field trials and demonstrations. The production of hecogenin from sisal has been transferred to firms engaged in the industry on satisfactory commercial terms, and cortisone is being produced from the hecogenin now available. In view of the favourable report of

* National Research Development Corporation. Report and Statement of Accounts for the Year 1st July, 1954, to 30th June, 1955. Pp. if +20. (London: H.M.S.o., 1956.) 1s, net. a firm of chemical engineering consultants, the Corporation is continuing to support the acetylene synthesis project at the Imperial College of Science and Technology, London. Development of an experimental prototype stereoscopic motion-picture camera was completed during the year, and the camera is extremely promising.

Of the new projects, the Corporation is supporting an extended design study at the Manchester College of Technology of the possibility of controlling machine tools directly with a digital computer, and is sponsoring the development and initial marketing of Prof. H. S. Lipson's optical diffractometer. It is also financing the research and development work on the application of Prof. G. Pontecorvo's technique for synthesizing new strains of non-sexually reproducing micro-organisms, and is participating in a joint project with the Department of Scientific and Industrial Research and the Herring Industry Board to develop full-scale prototype equipment for commercial trials of new techniques of fish-smoking. Established projects now proving a useful source of revenue include those on the Bailey bridge, the DennyBrown ship stabilizer, a technique for light-alloy cutting by electric arc, an air-position indicator, a course-setting dial-adjustment for aircraft, a backward-travelling-wave tube, a signalling system for teleprinter operation over radio links, a synthetic resin stoving enamel, a fire-fighting foam from degraded animal protein materials, a composition tablet for rendering brackish or sea water drinkable and an improved synthesis of an intermediate required in the production of the anti-malarial, 'Derraprim'.

\section{UNIVERSITIES COUNCIL FOR ADULT EDUCATION}

\section{REPORT FOR $1954-55$}

$T$

HE report of the Universities Council for Adult Education for the session $1954-55^{*}$ is critical of the Ashby report of adult education in Britain on two points: it has serious doubts regarding the administrative arrangements proposed for the annual assessment of grants to responsible bodies; and it regards the recommendation that a committee should be set up to advise the Minister of Education on the subjects and types of adult education courses which should receive priority in qualifying for grants as a serious threat to the academic freedom of the universities. The Council re-asserts its convietion that responsible bodies must truly exercise the responsibility of determining the form and content of their programmes, in shaping which consultation with the Ministry is always. welcomed. When the Minister of Education intimated his acceptance of the recommendations of the Ashby Committee, this particular recommendation was specifically excepted, and friendly discussions with the Ministry have led to a mutually acceptable arrangement for assessing grants. The new Further Education Grant Regulations, issued in July 1955, contained the statement, according with the cardinal recommendation of the Ashby Committee for more active but flexible control of expenditure by the Ministry, that "in determining * Universities Council for Adult Education. Report on the Year 1954-55. Pp. 24. (From the hono
Salt, University of Bristol, 1956.) 